\title{
Comparative Study on the Awareness, Availability and Patronage of Electronic Resources between Male and Female Students of AbubakarTafawa Balewa University Bauchi, Bauchi State-Nigeria
}

\author{
Suleiman Abdullahi, CLN \\ University Library, \\ Abubakar Tafawa Balewa University Bauchi, \\ Bauchi State-Nigeria \\ Yagana Musa, CLN \\ University Library \\ Nigerian Army University, Biu, Borno State-Nigeria
}

\author{
Aliyu, Isyaku Ahmad, CLN \\ University Library, \\ Abubakar Tafawa Balewa University Bauchi, \\ Bauchi State-Nigeria \\ Adamu Hassan, CLN \\ Muhammadu Wabi Library \\ Federal Polytechnic Bauchi, Bauchi State-Nigeria
}

\begin{abstract}
This study was conducted to examine the availability and patronage of electronic resources by male and female students in Abubakar Tafawa Balewa University Bauchi, Bauchi state, Nigeria. 1500 male and female students formed the population of the study. Survey research method was adopted. Questionnaire was used as an instrument for data collection. Frequency counts and simple percentages were used in analysing the data collected. The study revealed that female students of Abubakar Tafawa Balewa University Bauchi have rarely patronized electronic resources in the e-library and as such has tremendous impact on their level of awareness on global world of electronic information and thereby would affects their academic performances. The study recommended among others, awareness of the availability of electronic resources in the library and the need for the female students to acquire more skills in the use of electronic resources.
\end{abstract}

Keywords:- Electronic Resources, Availability, Patronage, University Students, Nigeria.

\section{INTRODUCTION}

Academic libraries in Nigerian universities have been making significant contribution to the mandates of their parent institution. These mandates are teaching, research and community services which are geared towards social, political and economic development of the country. Academic libraries provide bibliographic, and user services to staff, students and immediate communities of their respective institutions. These services are significant and crucial to the achievements of their institution's academic, intellectual and other interested staff and students. This position was supported by Adeniran (2013) when he asserts that "academic libraries are essential contributors to knowledge generation and serve a wide spectrum of knowledge seekers'. Therefore, the services provided by an academic library in a university reflect the quality of teaching and research in such a university (Aina, 2014).Libraries today are challenged to shoulder more responsibilities in their bid to provide services to their users. The adoption of modern technologies; the skyrocketing costs of library materials; and highly sophisticated patrons with their expectations of quality and efficient services are additional challenges that must be confronted.

The advent of Information and Communication Technology (ICT) has accelerated the availability and use of electronic resources in academic libraries because of high demand for relevant information by faculty members and students. In order to meet such demand, libraries and librarians have to address their role and position in relation to this global development. Thus, academic libraries now invest heavily in electronic resources.

In academic libraries, the electronic resources that are of critical importance for use are e-journals and e-books, because they are the e-version of the conventional books and journals found in the library. These e-resources are stored and organized in various databases to permit easy retrieval. Some of these databases are subject-based while others cover a wider-angle of subject areas. Publishers often have their own databases with all their publications while other agents collate publications from various databases to provide robust access to e-resources.

The undergraduates of university require information to satisfy their social and psychological needs to enhance their academic pursuit during their course of study in the university. The purpose of the university libraries is to provide adequate and relevant information resources in both print and electronic formats. The print resources like journal, textbooks, magazines, and reference materials and non-print materials, such as CD-ROM, A.V materials, microfilms, databases and e-resources, are to support class assignments, project work, term papers, proposals and presentations. An e-resource is materials encoded for manipulation by a computerized device, therefore, huge amount of money is earmarked in the university annual 
budget to be spent on e-library resources for the provision of timely information need of its users.

Students constitute the largest percentage of library users in universities.

\section{$>$ Statement of Problem}

The advent of electronic resources, accessible by remote means using various facilities, has created a level of convenience for students in using library facilities that are e-based. However, the researchers observed that despite the availability of e-resources in the library, the patronage of eresources by female students of Abubakar Tafawa Balewa University was very low to some extent when compared to their male counterpart. It is against this background that this study seeks to conduct a comparative study on the Availability and Patronage of Electronic Resources between Male and Female Students of Abubakar Tafawa Balewa University Bauchi.

\section{$>$ Objectives of the study}

The objectives of the study are to:

- Determine the types of e-resources available in Abubakar Tafawa Balewa University Library.

- Find out the level of awareness of e-resources by both male and female students of Abubakar Tafawa Balewa University, Bauchi

- Identify the frequency of patronage of e-resources by male and female students of Abubakar Tafawa Balewa University, Bauchi

- Determine the challenges of patronizing e-library resources by male and female students of Abubakar Tafawa Balewa, Bauchi

- Proffer strategies that will enhance the patronage of eresources in Abubakar Tafawa Balewa University Library.

\section{LITERATURE REVIEW}

Academic libraries are libraries attached to institutions of higher learning. The essence of the establishment of these libraries is to support the institutions academic programs in the areas of teaching, learning and research. Library is the intellectual "horse power" and "heartbeat" of any university and it provides all kinds of information materials to serve the needs of the users who are raison d'être for its existence (Owush and Issah, 2005).Institution libraries have varied users ranging from the entire students population of the university, academic staff and to nonacademic staff. According to Diogu (2011), the objective of any academic library, also called university library is to support teaching, learning, research activities of the parent institution. She added that it is an objective which is achieved through a systematic acquisition and organization of all forms of recorded and undocumented information resource of the academic community and helps them fulfill the curriculum requirements and promote studies and research (Ali, 2005). This makes it absolutely essential for a university library to possess the resources in both print and non-print materials that will enable it meet its goals.
However, the level of information services depends on the availability and utilization of the e-resources in library.

Electronic resources are the electronic representation of information. They are available in various forms like ebooks, digital libraries, online journal magazine, e-learning tutors and on line test. Because of the effective presentation with multimedia tools, these e-resources have become the source of information. Electronic resources delivers the collection of information as full text databases, e-journals, image collections, multimedia in the form of $\mathrm{CD}$, tape, internet, web technology etc. E-resources may include ejournals, e-discussions, e-news, data archives, e-mail on line chatting, etc can be called as an e-resources.

The level of availability and utilization of e-resources in any university library may influence the information services provision to students in that library. Adedeji (2000) noted that the level of e-resources available to any university library and the degree of use to which they are put, determine the information services delivery of library. However, e-resource when available and skillfully used, influences service provision and making them meaningful the more. Aguolu and Aguolu (2002) opined that availability should be viewed from national and instructional levels. They attributed the lack of availability of information sources to the steady proliferation of universities in Nigeria; both federal, state and private along with increases in students faculties and the diversification of courses and academic and research programmes, without adequate information sources to meet the actual and information needs. Aguolu (2000) also noted that Nigerian universities are in different stages of e-resources development, availability and use.

Studies have also been carried out on the use of electronic resources by teachers, students and research scholars of universities and research organizations. Seventy-eight per-cent $(78 \%)$ of the respondents feel that the use of the UGC - Infonet e-journals has created high dependency value on their research work and they needed current article alert services and electronic document supply services (Madhusudhan, 2008).

In the Nigerian context, Oduwole and Akpati (2003) investigated the accessibility and retrieval of electronic information at the University of Agriculture Library, Abeokuta, Nigeria. The 425 participants responded out of a survey population of 1,000 , giving a response rate of 53.87 percent. The study revealed that electronic information cuts across all members of the University community that it was to a greater extent easy to use and were satisfied with their search outputs. The constraints identified included insufficient number of terminals available for use despite high demand and inadequate electricity supply.

Availability of electronic information sources relates to the provision for and inclusion of the resources in the collection of the libraries at the disposal of users in academic institutions. In the Words of Roberts (2013), availability of electronic resources provides access to 
authoritative, reliable, accurate and timely access to information. In addition to this, the resources can enable innovation in teaching and increase timeliness in research. Awareness is part of availability and it indicates the extent to which users have information and knowledge of electronic resources being subscribed to. When users of a library have adequate information on the electronic resources being subscribed to they are encouraged to use them. Available ICT and e-resources must be known to the users. Madukoma, Onuoha and Ikonne (2014) identified lack of awareness as major contributing factor to non-use of e-resources.

However the use of these resources is likely to be influenced by availability of the resources. This implies that electronic resources must be made available in several brands to the users in their institutions. Their contents must also be publicized by the library in order to prompt their use. Some constraints may also affect the use of electronic resources. Consequently, this study investigated the availability, level of use and challenges to the use of electronic resources by female students of the Abubakar Tafawa Balewa University Bauchi, Bauchi state.

According to Shuling (2007), who analyzed the use of electronic resources in Shaanxi University of Science and Technology, the sample consists of 909 respondents of all types of library users. The study found that nearly $(80 \%)$ eighty percent of respondents knew little about electronic resources. Nearly half the respondents use both printed and electronic resources, followed by print periodicals. Ali (2005) highlights the use of electronic information services (EIS) among the users of Indian Institute of Technology (IIT) library in Delhi, India. Data was collected from three hundred IIT library users. Results revealed that 95 percent of users have awareness about EIS provided by the library. Also, Dadzie (2005) investigated the use of electronic resources by students and faculty of Asheshi University Ghana, to determine the level of use, the type of information accessed and the effectiveness of the library's communication tools for information research and problems faced in using electronic resources. Results indicated that 85 percent of respondents used the Internet to access information, and that respondents mainly accessed information in the library by browsing the shelves.

In the same vein, Rehman and Ramzy (2004) investigated the awareness and use of electronic information resources among health academics. Results showed that libraries are extensively used for research needs, preparation of lectures, and for obtaining current knowledge. Lack of time is the main reason given for not using electronic resources (37 percent). Unfamiliarity with computerized searching comes next (22.6percent). Majid and Abazova (1999) explored the use of electronic information sources relevant to computer literacy among academic staff of the International Islamic University, Malaysia. Nearly all respondents considered themselves to have good or very good computer skills. Azubogu and Madu (2007) observed that academic staffs of the Imo State University, Owerri, Nigeria, have resorted to the use of computer and Internet technologies to search for information because the university library lacks funds to subscribe to scholarly and research journals.

\section{METHODOLOGY}

A survey research design was adopted for this study and questionnaire was prepared to collect data from male and female student users of Abubakar Tafawa Balewa University Bauchi. Questionnaire contains various questions pertaining to the awareness, availability and patronage of e-resources. A total of 306 copies of questionnaire were distributed among the male and female students of the university based on Krejcie and Morgan table in which 266 copies of questionnaire were returned completed and valid for analysis. Data were analyzed using SPSS specifically descriptive statistics such as tables, frequency and percentages were used.

\section{RESULT AND DISCUSSION}

Data were analyzed and results presented in line with the study research questions.

Demographic characteristics:

\begin{tabular}{|c|c|c|}
\hline Gender & Frequency & Percentage \\
\hline Males & 164 & $61.7 \%$ \\
\hline Females & 102 & $38.3 \%$ \\
\hline Total & 266 & $100 \%$ \\
\hline
\end{tabular}

Table 1:- Gender Distribution of the Respondents

Table 1 showed the frequencies and percentages of male and female students, who participated in the study. Findings revealed that, $164(61.7 \%)$ of the respondents were male students while $102(38.3 \%)$ were females. In total, 266(86.9\%) respondents completed the questionnaire. This showed a very high response was recorded. 
ISSN No:-2456-2165

\begin{tabular}{|c|c|c|c|c|c|}
\hline \multirow{2}{*}{ e-Resource } & \multicolumn{2}{|c|}{ Male students } & \multicolumn{2}{c|}{ Female students } & Total \\
\cline { 2 - 6 } & AV & NA & AV & $80(30.1 \%)$ & $266(100 \%)$ \\
\hline E-Books & $154(57.9 \%)$ & $10(3.7 \%)$ & $22(8.3 \%)$ & $84(31.6 \%)$ & $266(100 \%)$ \\
\hline Online Database & $132(49.6 \%)$ & $32(12.0 \%)$ & $18(6.8 \%)$ & $99(37.2 \%)$ & $266(100 \%)$ \\
\hline Internet Services & $164(61.7 \%)$ & - & $3(1.1 \%)$ & & $266(100 \%)$ \\
\hline E-journals & $125(47.0 \%)$ & $39(14.7 \%)$ & $10(3.7 \%)$ & $92(34.6 \%)$ & $266(100 \%)$ \\
\hline Email Services & $102(38.3 \%)$ & $62(23.3 \%)$ & $43(16.2 \%)$ & $59(22.2 \%)$ & $266(100 \%)$ \\
\hline $\begin{array}{c}\text { Online Public } \\
\text { Access Cat. } \\
\text { (OPAC) }\end{array}$ & - & $164(61.7 \%)$ & - & $102(38.3 \%)$ & \\
\end{tabular}

Table 2:- Electronic Resources available in ATBU e-library

Result from table 2, showed that internet services 164(61.7\%) ranked the highest electronic resources available in ATBU Library, followed by e-books with 154(57.9\%) respondents. Online database 132(49.6\%) ranked third while e-journals recorded $125(47.0 \%)$. The study revealed that the male students' responses on the available e-resources were much higher $164(61.7 \%)$ than the female students $22(8.3 \%)$. The result of the study also showed the availability of e-resources in ATBU Library.

\begin{tabular}{|c|c|c|c|}
\hline Respondents & Aware & Not Aware & Total \\
\hline Male & $132(49.6 \%)$ & $32(12.0 \%)$ & $164(61.6 \%)$ \\
\hline Female & $21(7.9 \%)$ & $81(30.5 \%)$ & $102(38.4 \%)$ \\
\hline Total & $\mathbf{1 5 3}(\mathbf{5 7 . 5 \%})$ & $\mathbf{1 1 3 ( 4 2 . 5 \% )}$ & $\mathbf{2 6 6}(\mathbf{1 0 0 \%})$ \\
\hline
\end{tabular}

Table 3:- Students Level of Awareness of e-Resources in ATBU Library

Table 3 depicted the respondents' level of awareness of e-resources in the ATBU Library. Result showed that 132(49.6\%) of the male students were aware of the e-library resources as against their females counterpart which only $21(7.9 \%)$ of them were aware of the e-library resources. This implies that the majority of the female students were not aware of the electronic resources in ATBU Library and that could be the reason why there was a very low patronage of the resources by the later group of the respondents as shown in the table 4 below.

\begin{tabular}{|c|c|c|c|c|c|}
\hline Gender & Very often & Often & Occasional & Rarely & Not at all \\
\hline Male Students & $84(31.6 \%)$ & $32(12.0 \%)$ & $19(7.1 \%)$ & $24(9.0 \%)$ & $5(1.9 \%)$ \\
\hline Female Students & - & $22(8.3 \%)$ & $19(7.1 \%)$ & $18(6.8 \%)$ & $43(16.2 \%)$ \\
\hline
\end{tabular}

Table 4:- Respondents' Frequency Patronage of e-Library Resources in ATBU Library.

Table 4 showed the frequency of respondents' patronage of the e-library resources in the ATBU Library. Findings revealed that $84(31.6 \%)$ and $32(12.0 \%)$ of the male respondents were very often and often patronized the e-library resources respectively against the $22(8.3 \%)$ and $19(7.1 \%)$ of the female students respectively on the same questions. The Result therefore, showed that, female students had a very low patronage to e-resources than the male students.

\begin{tabular}{|c|c|c|c|c|c|}
\hline \multirow{2}{*}{ Reasons } & \multicolumn{2}{|c|}{ Male students } & \multicolumn{2}{|c|}{ Total } \\
\cline { 2 - 5 } & Yes & No & Yes & No & \\
\hline View Email & $57(21.4 \%)$ & $107(40.2 \%)$ & $24(9.0 \%)$ & $78(29.3 \%)$ & $266(100 \%)$ \\
\hline Leisure & $62(23.3 \%)$ & $102(38.3 \%)$ & $36(13.5 \%)$ & $66(24.8 \%)$ & $266(100 \%)$ \\
\hline Assignment & $111(41.7 \%)$ & $53(19.9 \%)$ & $58(21.8 \%)$ & $44(16.5 \%)$ & $266(100 \%)$ \\
\hline View latest information. & $74(27.8 \%)$ & $90(33.8 \%)$ & $12(4.5 \%)$ & $90(33.8 \%)$ & $266(100 \%)$ \\
\hline Research & $135(50.8 \%)$ & $29(10.9 \%)$ & $58(21.8 \%)$ & $44(16.5 \%)$ & $266(100 \%)$ \\
\hline Complement classroom work. & $121(45.5 \%)$ & $43(16.2 \%)$ & $45(16.9 \%)$ & $57(21.4 \%)$ & $266(100 \%)$ \\
\hline
\end{tabular}

Table 5:- Reasons for Patronizing the e-Library Resources.

Table 5 presented the various reasons why students of ATBU patronized e-library resources. Findings revealed that $135(50.8 \%)$ and $58(21.8 \%)$ of the male and female students' respondents indicated that they patronized the e-library for research. The result also revealed that $57(21.4 \%)$ and $24(9.0 \%)$ of the male and female respondents respectively, indicated that they patronized the e-library resources in order to view their emails only. Similarly, 74(27.8\%) male respondents and $12(5 \%)$ female respondents also respectively indicated that they patronized the e-library for the latest information while $62(23.83 \%)$ of male and $36(13.5 \%)$ female respondents patronized the e-resources for leisure. This findings revealed that, the major reason ATBU Library Users (male and females) patronized the e-resources was for research. 
ISSN No:-2456-2165

\begin{tabular}{|c|c|c|c|c|c|}
\hline \multirow{2}{*}{ S/N } & Challenges & \multicolumn{2}{|c|}{ Male } & \multicolumn{2}{|c|}{ Female } \\
\cline { 3 - 5 } & & $($ Yes) & $(\mathbf{N o})$ & $($ Yes) & (No) \\
\hline 1. & $\begin{array}{c}\text { Difficulty in access to a wider } \\
\text { information resources }\end{array}$ & $21(7.9 \%)$ & $143(53.7 \%)$ & $72(27.1 \%)$ & $30(11.3 \%)$ \\
\hline 2. & $\begin{array}{c}\text { Inadequate access to current } \\
\text { information materials }\end{array}$ & $78(29.3 \%)$ & $86(32.3 \%)$ & $59(22.2 \%)$ & $43(16.2 \%)$ \\
\hline 3. & Epileptic power supply & $128(48.1 \%)$ & $36(13.5 \%)$ & $72(27.1 \%)$ & $30(11.3 \%)$ \\
\hline 4. & Poor or inadequate bandwidth & $143(53.8 \%)$ & $21(7.9 \%)$ & $81(30.4 \%)$ & $21(7.9 \%)$ \\
\hline 5. & $\begin{array}{c}\text { Difficulty in accessing current } \\
\text { information resources }\end{array}$ & $28(10.5 \%)$ & $136(51.1 \%)$ & $68(25.6 \%)$ & $34(12.8 \%)$ \\
\hline 6. & Unfriendly user interface & $41(15.4 \%)$ & $123(46.2 \%)$ & $57(21.4 \%)$ & $45(16.9 \%)$ \\
\hline 7. & Lack of required searching skills & $122(45.9 \%)$ & $42(15.8 \%)$ & $91(34.2 \%)$ & $11(4.1 \%)$ \\
\hline
\end{tabular}

Table 6:- Challenges of patronizing e-Library Resources by Male and Females Students in Abubakar Tafawa Balewa, Bauchi

Table 6 sought for information from the respondents on the challenges facedwhen patronizing the e-library resources. Study showed that $143(53.7 \%$ ) of the male respondents indicated that Poor or inadequate bandwidth was the major challenge they faced when patronizing the e-resources in ATBU Library, this was followed by 128(48.1\%) of the male respondents who indicated that Epileptic power supply as another challenge they faced while patronizing the e-resources. The next in this category of users (male students) was Lack of required searching skills which recorded 122(45.9\%) respondents. However, the result from the female students was different, in which the findings showed that 91(34.2\%) of the respondents were of the view that Lack of required searching skills was the major challenge they faced when patronizing the e-resources in ATBU Library. It was followed by Poor or inadequate bandwidth which scored $81(30.4 \%)$ of the responses recorded while Difficulty in access to a wider information resources and Epileptic power supply that had $72(27.1 \%)$ each of the female respondents. This study showed that the male students of ATBU were more committed to patronizing e-library resources which kept them abreast to current world information than their female counterparts. This could be attributed to the fact that, they were more aware of the e-resources in ATBU Library as reflected in table 3 above.

\begin{tabular}{|c|c|c|c|c|c|c|c|c|c|c|}
\hline \multirow[t]{3}{*}{ Strategies } & \multicolumn{10}{|c|}{ Response } \\
\hline & \multicolumn{2}{|c|}{ SA } & \multicolumn{2}{|c|}{$\mathbf{A}$} & \multicolumn{2}{|c|}{ UD } & \multicolumn{2}{|c|}{ DA } & \multicolumn{2}{|c|}{ SD } \\
\hline & $\mathbf{M}$ & $\mathbf{F}$ & $\mathbf{M}$ & $\mathbf{F}$ & $\mathbf{M}$ & $\mathbf{F}$ & $\mathbf{M}$ & $\mathbf{F}$ & $\mathbf{M}$ & $\mathbf{F}$ \\
\hline $\begin{array}{l}\text { Awareness on } \\
\text { the availability } \\
\text { of e-resources }\end{array}$ & $\begin{array}{c}123 \\
(46.2 \%)\end{array}$ & $\begin{array}{c}76 \\
(28.6 \%)\end{array}$ & $\begin{array}{c}22 \\
(8.3 \%)\end{array}$ & $\begin{array}{c}21 \\
(7.9 \%)\end{array}$ & $\begin{array}{c}6 \\
(2.2 \%)\end{array}$ & $\begin{array}{c}3 \\
(1.1 \%)\end{array}$ & $\begin{array}{c}7 \\
(2.6 \%)\end{array}$ & $\begin{array}{c}1 \\
(0.4 \%)\end{array}$ & $\begin{array}{c}6 \\
(2.2 \%)\end{array}$ & $\begin{array}{c}1 \\
(0.4 \%)\end{array}$ \\
\hline $\begin{array}{l}\text { Provision of } \\
\text { quality } \\
\text { information } \\
\text { resources. }\end{array}$ & $\begin{array}{c}88 \\
(33.1 \%)\end{array}$ & $\begin{array}{c}65 \\
(24.4 \%)\end{array}$ & $\begin{array}{c}51 \\
(19.2 \%)\end{array}$ & $\begin{array}{c}31 \\
(11.6 \%)\end{array}$ & $\begin{array}{c}5 \\
(1.9 \%)\end{array}$ & $\begin{array}{c}3 \\
(1.1 \%)\end{array}$ & $\begin{array}{c}11 \\
(4.1 \%)\end{array}$ & $\begin{array}{c}2 \\
(0.8 \%)\end{array}$ & $\begin{array}{c}9 \\
(3.4 \%)\end{array}$ & $\begin{array}{c}1 \\
(0.4 \%)\end{array}$ \\
\hline $\begin{array}{l}\text { Improved } \\
\text { access to } \\
\text { internet } \\
\text { service }\end{array}$ & $\begin{array}{c}141 \\
(53.0 \%)\end{array}$ & $\begin{array}{c}68 \\
(25.6 \%)\end{array}$ & $\begin{array}{c}11 \\
(4.1 \%)\end{array}$ & $\begin{array}{c}23 \\
(8.6 \%)\end{array}$ & $\begin{array}{c}2 \\
(0.8 \%)\end{array}$ & $\begin{array}{c}8 \\
(3.0 \%)\end{array}$ & $\begin{array}{c}3 \\
(1.1 \%)\end{array}$ & $\begin{array}{c}2 \\
(0.8 \%)\end{array}$ & $\begin{array}{c}7 \\
(2.6 \%)\end{array}$ & $\begin{array}{c}1 \\
(0.4 \%)\end{array}$ \\
\hline $\begin{array}{l}\text { Access to } \\
\text { current and } \\
\text { up-to-date } \\
\text { Information }\end{array}$ & $\begin{array}{c}101 \\
(38.0 \%)\end{array}$ & $\begin{array}{c}57 \\
(21.4 \%)\end{array}$ & $\begin{array}{c}27 \\
(10.1 \%)\end{array}$ & $\begin{array}{c}38 \\
(14.3 \%)\end{array}$ & $\begin{array}{c}10 \\
(3.8 \%)\end{array}$ & $\begin{array}{c}6 \\
(2.2 \%)\end{array}$ & $\begin{array}{c}14 \\
(5.3 \%)\end{array}$ & $\begin{array}{c}1 \\
(0.4 \%)\end{array}$ & $\begin{array}{c}12 \\
(4.5 \%)\end{array}$ & - \\
\hline $\begin{array}{l}\text { Access to a } \\
\text { wider range of } \\
\text { information }\end{array}$ & $\begin{array}{c}76 \\
(28.6 \%)\end{array}$ & $\begin{array}{c}49 \\
(18.4 \%)\end{array}$ & $\begin{array}{c}40 \\
(15.0 \%)\end{array}$ & $\begin{array}{c}36 \\
(13.5 \%)\end{array}$ & $\begin{array}{c}15 \\
(5.6 \%)\end{array}$ & $\begin{array}{c}17 \\
(6.4 \%)\end{array}$ & $\begin{array}{c}18 \\
(6.8 \%)\end{array}$ & - & $\begin{array}{c}15 \\
(5.6 \%)\end{array}$ & - \\
\hline $\begin{array}{l}\text { Uninterrupted } \\
\text { power supply }\end{array}$ & $\begin{array}{c}132 \\
(49.6 \%)\end{array}$ & $\begin{array}{c}52 \\
(19.5 \%)\end{array}$ & $\begin{array}{c}19 \\
(7.1 \%)\end{array}$ & $\begin{array}{c}43 \\
(16.2 \%)\end{array}$ & $\begin{array}{c}3 \\
(1.1 \%)\end{array}$ & $\begin{array}{c}5 \\
(1.9 \%)\end{array}$ & $\begin{array}{c}7 \\
(2.6 \%)\end{array}$ & $\begin{array}{c}1 \\
(0.4 \%)\end{array}$ & $\begin{array}{c}3 \\
(1.1 \%)\end{array}$ & $\begin{array}{c}1 \\
(0.4 \%)\end{array}$ \\
\hline
\end{tabular}

Table 7:- Strategies that will enhance the patronage of e-resources by Male and Female Students of ATBU.

Result in table 7, identified some strategies that will enhance students' patronage of the e-resources in ATBU Library. The table revealed that the major strategy that will enhance the patronage of e-resources in ATBU Library was improved access to internet service with the total of $141(53.0 \%)$ male respondents. This was followed by uninterrupted power supply $132(49.6 \%)$ of the male respondents while $123(46.2 \%)$ of male respondents strongly agreed with Awareness on the availability of eresources as another strategy to enhance the patronage of the e-resources in the library studied. The findings from female respondents revealed that the major strategy was 
Awareness on the availability of e-resources with $76(28.6 \%)$ of the responses strongly agreed, followed by improved access to internet service which scored $68(25.6 \%)$ of the responses and Provision of quality information resources which has $65(24.4 \%)$ of the female respondents as strategies that will enhance patronage of eresources in ATBU Library.

\section{DISCUSSION OF RESULTS}

Findings in this study revealed that e-books, internet services, e-journals, and email services were available for users to access in ATBU Library. However, the study indicated that $39(14.7 \%), 59(22.2 \%)$ of male and female students stated in their responses that e-journal and email services as well as OPAC services were not available during the study. The research study also indicated that $132(49.6 \%)$ male and $21(7.9 \%)$ female students were aware of e-resources in the library while, $81(30.5 \%)$ of the female respondents stated that they were ignorant of the availability of e-resources in ATBU Library.

The study also showed that female students occasionally patronize e-library $19(7.1 \%)$; and rarely patronize the library $18(6.8 \%)$; while $5(1.9 \%)$ of them were not patronizing at all. However, the male students were very often patronized the e-library, $84(31.6 \%)$, often patronized $32(12.0 \%)$, occasionally $19(7.1 \%)$ while some of the female students did not patronize at all 5(1.9\%).

The study revealed some challenges which the students of ATBU Bauchi faced by while patronizing the elibrary such as; difficulty in access to a wider information resources, inadequate access to current information materials and poor academic performance due to lack of access to current resources. Some strategies that would motivate the female students to be patronizing the e-library and accessing the available electronic resources, were therefore, proffered which include among others; awareness of the availability of e-resources in the library, access to a wider range of information resources and provision of uninterrupted power supply to enhance library operations as well as provision of current and up-to-date information resources to students and researchers so as to derived the benefit of available contents abound in the library.

\section{CONCLUSION}

Based on the findings of the study, the following conclusions are drawn:

$>$ Electronic information resources like internet, e-mail services, online databases, electronic databases, and electronic journals were available for use in ATBU library.

$>$ These electronic information resources were provided to male and female students of the university, to support their academic course work, and to avail them with the world happenings globally. Also, to enrich them with current and varied information resources in various academic fields for their consultation, as well as for research needs.
The availability of these resources will benefits the female students who occasionally or rarely patronize the e-resources library such as access to current and up-todate information, faster and easier access to information, and access to a wider range of information.

\section{RECOMMENDATIONS}

The following recommendations are made, based on the findings of this study

$>$ The university library should intensify the awareness on the availability and use of library e-resources especially to female university students so that they can benefit from the electronic library resources in ATBU.

$>$ Management of the ATBU Library should emphasize on provision of more electronic e-resources and encouragement should be given to femalestudents to patronize the e-library.

$>$ Training and retraining of library personnel should be provided to assist the students especially, the female ones on how to use the available e-library resources.

$>$ Poor or inadequate bandwidth, Epileptic power supply and Lack of required searching skills by the students should address so as to improve the level of patronage of e-resources in ATBU Library.

As strategies to enhance the patronage of e-resources in ATBU Library, the Library management should improve access to internet service and access to current and up-to-date Information as well.

\section{REFERENCES}

[1]. Adeniran, P. (2013). Usage of Electronic Resources by Undergraduates at the Redeemer's University, Nigeria.International Journal of Library and Information Science 5(10),319-324. Available at http:/www.academicjournals.org/IJLIS

[2]. Adedeji, O.A (2000). The development of modern information and communication technology in Ibadan: Creation educational publications Ltd. 58.

[3]. Aguolu, C.C, Aguolu, I.E (2002). Libraries and information management in Nigeria.Maiduguri: EdLinform services.

[4]. Aina, L. O. (2014) .Library and information science Text for Africa.Ibadan; Third world Information Service Ltd.

[5]. Ali, Naushad (2005). The use of electronic resources at IIT Delhi Library; a study of search behaviours. The Electronic Library Vol.23 no. 6: 691 - 700

[6]. Azuobogu, S., and Madu, E.C (2007). Technology skills for information handling: New implication for library profession in Nigeria.International Journal of Information and Communication Technology. 5(1).S

[7]. Dadzie, P. S. (2005). Electronic Resources: access and usage at Ashesi University College. Campus - wide Information Systems 22(5) Available at: http//www.emeraldinsight.com. Accessed on 8th November, 2011

[8]. Diogu, C. (2011). Principle of educational administration and planning.Okgwe: Ajack Printing Press. 
[9]. Issah, O and Owush, A (2005). Application of information and communication technology to library services at federal university of technology Akure Ondo state, Nigeria. Library Philosophy and practice. Retrieved from www. webpages. uidaho.edu.

[10]. Madhusudhan, M. (2008). Use of UGC infonet journals by the Research Scholars of University of Delhi”,Library Hi Tech, Vol. 26. No. 3. pp. 369 - 386.

[11]. Madukoma, E., Onuoha, U.D., and Ikonne, S.u (2014). Reference services in library and information centres in the $21^{\text {st }}$ centuary. Modern Library and Information Science for Information Professionals in Africa.Ibadan:Textlinks.47-74

[12]. Majid, S. (1999), "Computer literacy and use of electronic information sources by academics: a case study of International Islamic University Malaysia"

[13]. Oduwole A. A., \&Akpati, C. B. (2003). Accessibility and retrieval of electronic information at the University of Agriculture Library Abeokuta, Nigeria. 52(5), $228 \quad-233, \quad$ Available at: http://www.emeraldinsight.com/researchregister.

[14]. Rehman, Shafiq Ur, FarzanaShafique, and Khalid Mahmood (2014). "A survey of user perception and satisfaction with reference services in University Libraries of Punjab." Library Philosophy and Practice, June. http://www.webpages.uidaho.edu/ mbolin/rehmanshafique-mahmood.htm.

[15]. Shuling, W. (2007).Investigation and analysis of current use of electronic resources in University Libraries.Library Management, 28(1), 72-88.Asian libraries 8(4), 100-111.

[16]. Roberts A. (2013)."Use of electronic information resources and academic performance of University Teachers: A case study." European Journal of Business and Management 5(14): 46-52. http://www.iiste.org/Journals/index.php/EJBM/article/ view/6166/6293. 